\title{
A Comparison Of Multi Carrier Pwm Techniques Using Z-Source Five Level Diode Point Clamped Inverter
}

\author{
F.X. Edwin Deepak ${ }^{1}$, R.Ranjitha ${ }^{2}$ \\ ${ }^{1}$ (Assistant professor, EEE, P.S.N.A.C.E.T/ Anna university, Tamilnadu, India) \\ ${ }^{2}$ (PG Scholar, EEE, P.S.N.A.C.E.T/ Anna university, Tamilnadu, India)
}

\begin{abstract}
Multilevel Inverter (MLI) has been recognized as an attractive topology for high voltage $D C-A C$ conversion. Function of a multilevel inverter is to synthesize a desired voltage wave shape from several levels of DC voltages. But the main drawback of MLI is its output voltage amplitude is limited to DC sources voltage summation. To overcome this limitation, a Z-source five-level neutral point clamped inverter has been proposed in this work. In the proposed topology output voltage amplitude can be boosted with $Z$ network shoot-through state control. It employs $Z$ network between the DC source and inverter circuitry to achieve boost operation. The output voltage of proposed inverter can be controlled using modulation index and shoot through state.

This research work focuses on multicarrier pulse width modulation (MCPWM) strategy for the single phase five level Z-source neutral point clamped inverter. Performance parameters of five-level Z source neutral point clamped inverter have been analyzed. A simulation model of five level Z-source neutral point clamped inverter developed using MATLAB/SIMULINK 7.13 and its performance has been analyzed.
\end{abstract}

Keywords - Multilevel Inverter (MLI), Z-source Inverter, Multicarrier pulse width modulation.

\section{INTRODUCTION}

There are various applications varying from medium voltage to high voltage high power application which requires $\mathrm{DC}$ to $\mathrm{AC}$ conversion using multilevel inverters. The research on multilevel inverter [1] is ongoing further to reduce the number of switching devices count to reduce the manufacturing cost, capacitor voltage balancing. The inverters with number of voltage levels equal to three or above than that are known as the multilevel inverters. Multilevel inverters are capable of producing high power high voltage as the unique structure of the multilevel voltage source inverter allows reaching high voltages with low harmonics without the use of transformers or series connected synchronized switching devices. As the number of voltage levels increases, the harmonic content of the output voltage waveform decreases. The synthesized multilevel outputs are superior in quality which results in reduced filter requirements. There are three major multilevel voltagesource inverter topologies neutral-point clamped inverter (i.e. Diode clamped), flying capacitor (capacitorclamped) and cascaded H-bridge multilevel inverter. There are also various other topologies which have been proposed and have successfully adopted in various industrial applications. The novel universal multi-carrier PWM[2] control scheme is used .This paper mainly focuses mainly on the neutral point clamped inverter topology Due to the modularity of the neutral point clamped multilevel inverter it can be stacked easily for high power and high voltage applications.

As aforesaid discussion indicates, multilevel inverters have been attracting lot of attention in high power and high voltage applications because they allow keeping the voltage stresses of power switches within rated limits [3] and thus adding to the reliability of the converter. However, another reliability issue is 'simplicity', as in electronics design, a system with more number of parts is more likely to fail. Classical multilevel topologies like Diode clamped (DC) converters, flying capacitors (FCs) converters and cascaded Hbridge (CHB) converters where used for increased number of voltage levels, pose drawbacks in terms of increased device count, complexity in implementation and increased cost. Therefore new topologies are being proposed and reported to reduce the overall count of active and passive devices for multilevel power conversion. The innovations in topological structures are being integrated with suitably selected modulation schemes and control strategies to minimize the requirement of solid state devices, energy storage components and DC sources. At the same time, these literatures present opportunity for further improvisations to increase number of levels in the output and increased redundant states to attain more flexibility in control.

In this research work the new configuration of the neutral point clamped single phase 5-level inverter is proposed which produces a five-level output voltage instead of three-level as in case of conventional neutral point clamped[4]. Also this new proposed topology produces the boost output voltage in comparison to conventional neutral point clamped topology which requires two neutral point clamped cells producing the five-level output voltage but the output voltage equal to the input DC voltage. Multilevel inverters are an 
attractive alternative to improve the output by synthesizing a staircase waveform imitating a sinusoidal waveform. Such a waveform not only has a low distortion, but it also reduces the dv/dt stress. Multilevel inverter topologies have the advantages of overcoming voltage limit capability of semiconductor switches, high voltage capability and better harmonic profile. Moreover, multilevel inverters can operate at both fundamental switching frequency and high switching frequency using PWM scheme.

\section{SYSTEM DISCRIPTIONS}

\section{Z-SourCe Neutral Point Clamped FiveleVel InVERTER}

In recent years, the multilevel voltage inverter is widely used in high power applications such as large induction motor drives, UPS systems and Flexible AC Transmission Systems (FACTS). Multilevel inverter [1] obtains a desired output voltage from several levels of input DC voltage sources. With an increasing number of DC voltage sources, the inverter voltage output waveform level increases. The multilevel inverters have more advantages which include lower semiconductor voltage stress, better harmonic performance, low Electro Magnetic Interference (EMI) and lower switching losses. Despite these advantages, multilevel inverters output voltage amplitude is limited to DC sources voltage summation. An intermediate DC to DC converter is required for the boost or buck operation of MLI output voltage. Occurring of short circuit can destroy multilevel inverters. To solve these problems, multilevel inverter based Z-source inverter is proposed in this work. The Z-source inverter [5] utilizes Z impedance network between the DC source and inverter circuitry to achieve buck-boost operation. The Z-Source inverter utilizes shoot-through state [4] to boost the input dc voltage of inverter switches when both switches in the same phase leg are on. The Z-Source inverters with respect to traditional inverters are lower costs, reliable, lower complexity and higher efficiency. This work proposed a neutral point clamped fivelevel Z-Source inverter is proposed for renewable energy systems and it employs Z network between the DC source and inverter circuitry to achieve boost operation. The output voltage of proposed inverter can be controlled using modulation index. Neutral point clamped Z-Source Multilevel inverter is analyzed with Multicarrier PWM technique [2]. Performance parameters have been analyzed for neutral point clamped ZSource MLI.

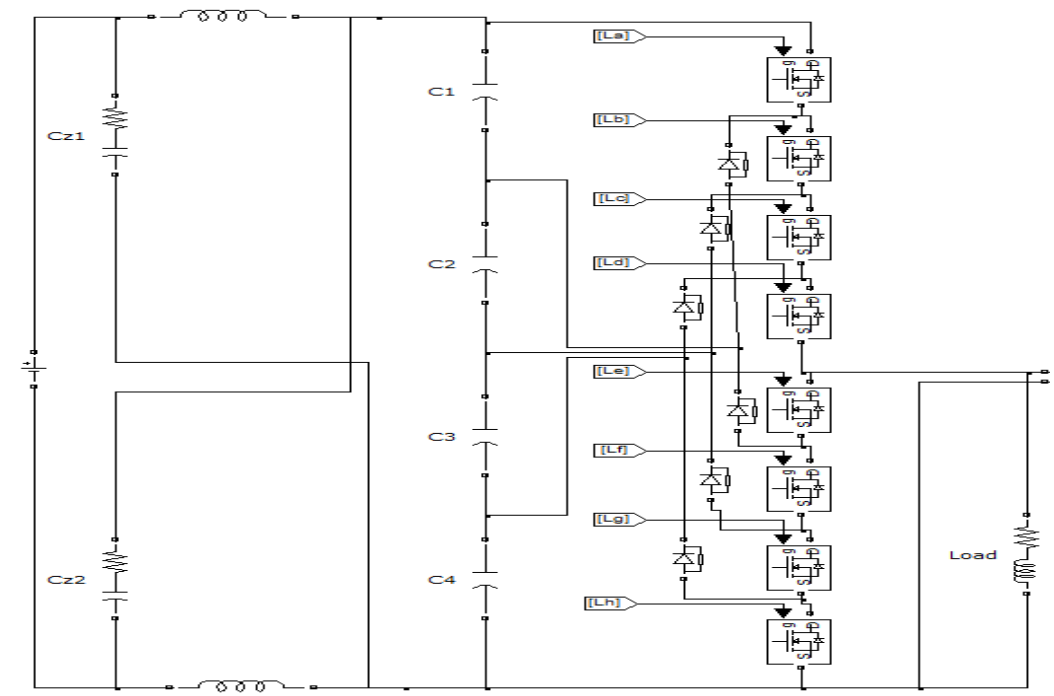

Fig.1.1 Neutral point clamped Z-Source five-level inverter

The circuit diagram of neutral point clamped Z-Source five-level inverter is shown in Fig. 1.1 It consists of series single-phase inverter units, $\mathrm{Z}$ impedances and DC voltage sources. DC sources can be obtained from batteries, fuel cells, solar cells [5]. Each bridge Z- Source inverter can generate three different output voltage +Vin, 0 , -Vin. Output voltage can be higher than the input voltage when boost factor, B $>1$. This topology has an extra switching state: shoot through state as compared to cascaded H-bridge inverters. During the shoot-through state, the output voltages of $\mathrm{Z}$ networks are zero. The inverter topology is based on the series connection of single-phase inverters with single impedance dc sources. The resulting phase voltage is synthesized by the addition of the voltages generated by the different cells. The number of switching devices are $(\mathrm{n}-1) * 2$, main diodes are $(\mathrm{n}-1) * 2$, clamping diodes are $(\mathrm{n}-1)(\mathrm{n}-2)$, dc bus capacitor are $(\mathrm{n}-1)$ where $\mathrm{n}$ is the number of cells. 


\section{Multi-Carrier Pulse With Modulation}

This section of the chapter extends the principles of carrier-based PWM that are used for multilevel inverter. There are three alternative PWM strategies with differing phase relationships:

2.1 Phase Disposition (PD)

2.2 Phase Opposition Disposition (POD)

2.3 Alternative Phase Opposition Disposition (APOD)

2.1 PHASE DISPOSITION PWM (PDPWM)

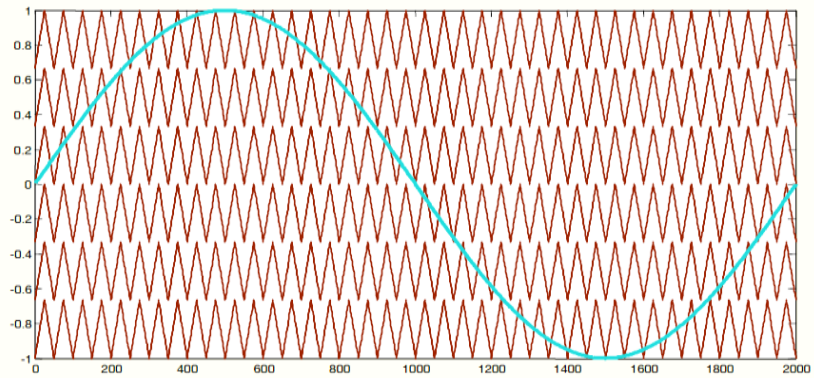

Fig. 2.1 Carrier Position for Phase Disposition

The carriers are in phase across all the bands .The zero reference is placed in the middle of the carrier sets. For this technique, significant harmonic energy is concentrated at the carrier frequency, but since it is a cophasal component, it doesn't appear in the line-to-line voltage.

\subsection{Phase Opposition Disposition Pwm (Podpwm)}

All the carriers above the zero reference are in phase and carriers below the zero reference are also in phase but are phase shifted by $180^{\circ}$ with respect to that above zero reference. The significant harmonics are located around the carrier frequency, for both the phase and line-to-line voltage waveform.

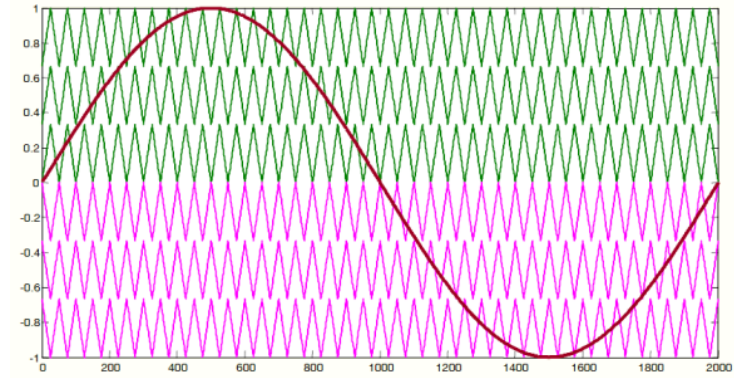

Fig.2.2 Carrier Position for Phase Opposition Disposition

\subsection{Phase Opposition Disposition Pwm (Podpwm)}

Carriers in adjacent bands are phase displaced by $180^{\circ}$. With this method, the most significant harmonics are centered as side bands around the carrier.

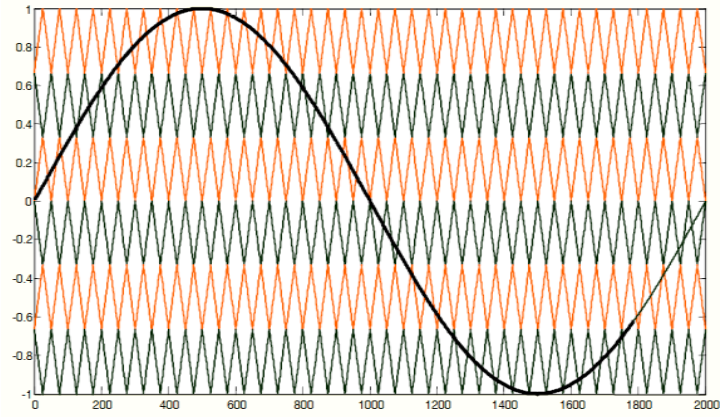

Fig.2.3 Carrier Position for Alternative Phase Opposition Disposition 


\section{Simulation Results Of Proposed Neutral Point Clamped Inverter}

The Z-source neutral point clamped fivelevel inverter is modelled in SIMULINK using power system block set. Switching signals for neutral point clamped multilevel inverter using MCSPWM strategies are simulated. Simulations are performed for different values of $\mathrm{m}$ a ranging from 0.8 to 1 and the corresponding \% THD are measured using the FFT block and their values are listed in Table 3.7-3.10 Figure 3.1-3.6 shows the proposed simulink diagram of Z-source neutral point clamped five level inverter with multicarrier PWM technique. Figure 3.1 - 3.6 show the simulated output voltage of Z source NPCMLI and their harmonic spectra. Figure.3.1 displays the five level output voltage generated by PDPWM switching strategy and its FFT plot is shown in Figure 3.2. Figure 3.3show the five level output voltage generated by PODPWM strategy and its FFT plot is shown in Figure 3.4. Figure 3.5 show the five level output voltage generated by APODPWM strategy and its FFT plot is shown in Figure 3.6. Tables 3.7-3.8 displayed the THD analysis, VRMS (fundamental) of the output voltage, Crest Factor (CF) and Form Factor (FF) for various modulation indices of $\mathrm{Z}$-Source five level neutral point clamped inverter respectively.

The following parameter values are used for simulation: $V_{1}=400 \mathrm{Vdc}$ and $\mathrm{Load} R=1000, \mathrm{~L}=100 \mathrm{e} 3$

\subsection{Phase Disposition (Pd)}

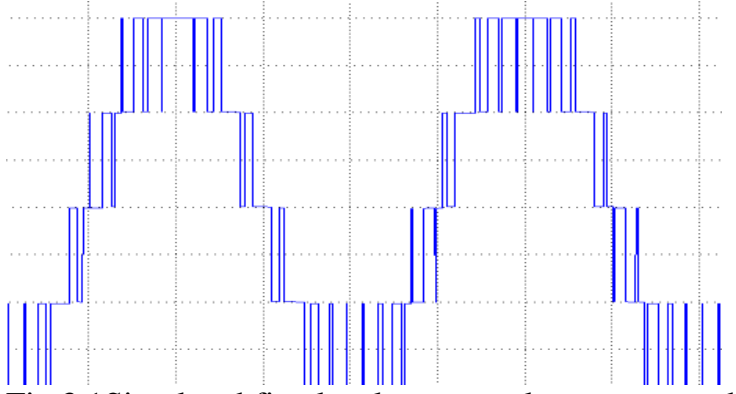

Fig.3.1Simulated five level output voltage generated by PDPWM technique for RL load with $\mathrm{m}_{\mathrm{a}}=0.9$

\subsection{Phase Opposition Disposition (Pod)}

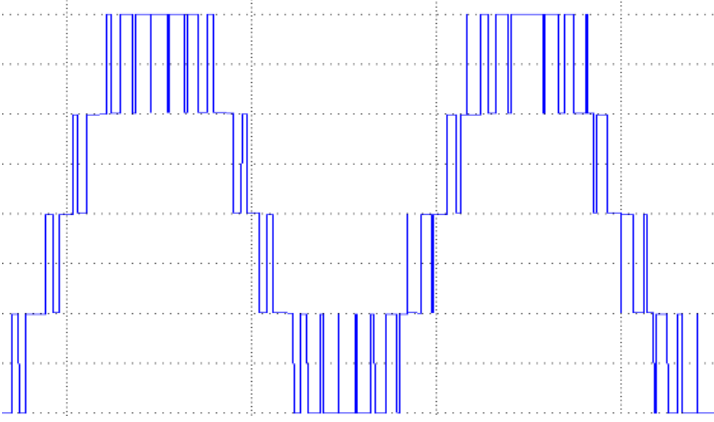

Fig.3.3 Simulated 5 level output voltage generated by POD technique for RL load with $\mathrm{m}_{\mathrm{a}}=0.9$

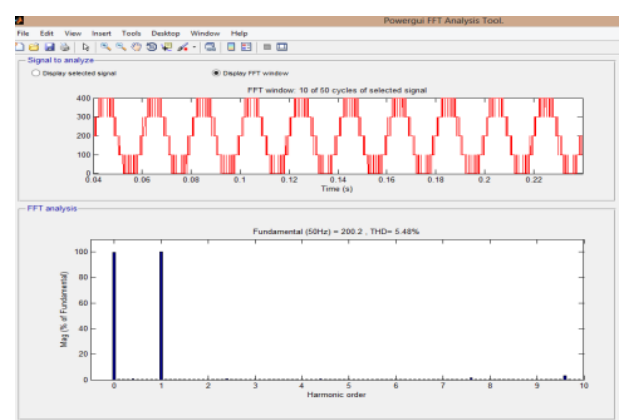

Fig.3.2 FFT- harmonic spectrum of output of PDPWM strategy with $\mathrm{m}_{\mathrm{a}}=0.9$

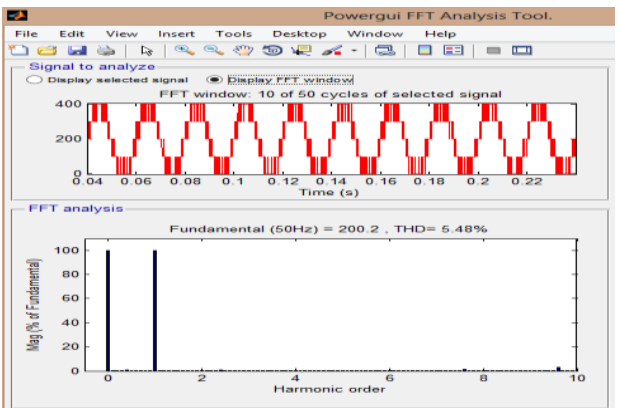

Fig.3.4 FFT- harmonic spectrum of output of PODPWM strategy with $\mathrm{m}_{\mathrm{a}}=0.9$

\subsection{Alternative Phase Opposition Disposition (Apod)}

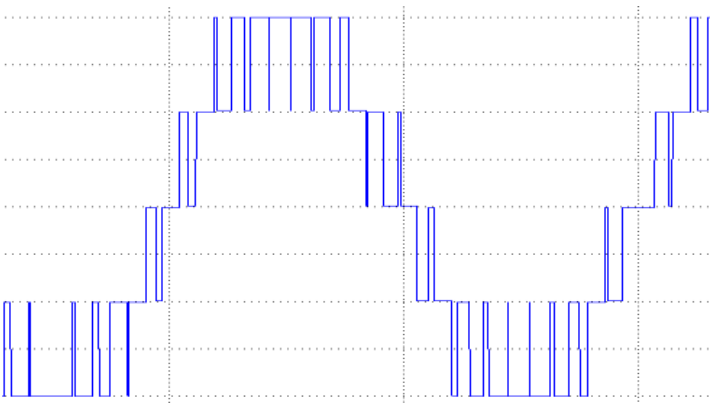

Fig.3.5 Simulated 5 level output voltage generated by APOD technique for RL load with $\mathrm{m}_{\mathrm{a}}=0.9$

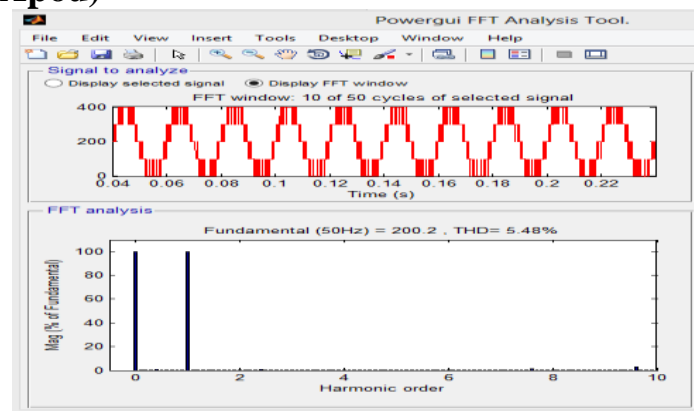

Fig.3.6 FFT- harmonic spectrum of output of APODPWM strategy with $\mathrm{m}_{\mathrm{a}}=0.9$ 
Table.3.7THD Calculation for Various MCPWM method

\begin{tabular}{|c|c|c|c|}
\hline \multirow{2}{*}{ Modulation Index (MI) } & \multicolumn{3}{|c|}{ Total Harmonics Distortion (\% THD) } \\
\cline { 2 - 4 } & PD & POD & APOD \\
\hline 1.0 & $5.48 \%$ & $5.54 \%$ & $5.44 \%$ \\
\hline 0.95 & $5.81 \%$ & $5.81 \%$ & $5.76 \%$ \\
\hline 0.90 & $6.06 \%$ & $6.12 \%$ & $6.06 \%$ \\
\hline 0.85 & $6.41 \%$ & $6.37 \%$ & $6.43 \%$ \\
\hline 0.80 & $6.79 \%$ & $6.86 \%$ & $6.78 \%$ \\
\hline
\end{tabular}

Table.3.8 VRMS (fundamental) of output voltage for different $\mathrm{m}_{\mathrm{a}}$

\begin{tabular}{|c|c|c|c|}
\hline \multirow{2}{*}{ Modulation Index (MI) } & \multicolumn{3}{|c|}{ RMS Voltage (Volts) } \\
\cline { 2 - 4 } & PD & POD & APOD \\
\hline 1.0 & 141.5 & 141.5 & 141.5 \\
\hline 0.95 & 134.5 & 134.6 & 134.5 \\
\hline 0.90 & 127.5 & 127.5 & 127.5 \\
\hline 0.85 & 120.3 & 120.3 & 120.4 \\
\hline 0.80 & 113.1 & 113.2 & 113.1 \\
\hline
\end{tabular}

For a pure sinusoidal waveform this effective or R.M.S. value will always be equal to $1 / \sqrt{ } 2 \times V_{\max }$ which is equal to $0.707 \times \mathrm{V}_{\max }$

Table 3.9 Crest tor $(\mathrm{CF})$ of output voltage for different $\mathrm{m}_{\mathrm{a}}$

For a pure sinusoidal waveform the Crest Factor will always be equal to 1.414

$$
\text { Crest Factor }=\frac{\text { Peak Value }}{\text { R.M. Svalue }}=\frac{V_{\max }}{0.707 \times V_{\max }}
$$

\begin{tabular}{|c|c|c|c|}
\hline $\mathrm{m}_{\mathrm{a}}$ & PD & POD & APOD \\
\hline 1 & 1.4148 & 1.4141 & 1.4148 \\
\hline 0.95 & 1.4148 & 1.4138 & 1.4141 \\
\hline 0.9 & 1.4149 & 1.4141 & 1.4141 \\
\hline 0.85 & 1.4147 & 1.4147 & 1.4136 \\
\hline 0.8 & 1.4146 & 1.4131 & 1.4146 \\
\hline
\end{tabular}

Table.3.10 Form Factor (FF) of output voltage for different $\mathrm{m}_{\mathrm{a}}$

\begin{tabular}{|c|c|c|c|}
\hline $\mathrm{m}_{\mathrm{a}}$ & PD & POD & APOD \\
\hline 1 & 1.109 & 1.1101 & 1.1101 \\
\hline 0.95 & 1.1095 & 1.1103 & 1.1101 \\
\hline 0.9 & 1.1095 & 1.1101 & 1.1101 \\
\hline 0.85 & 1.1096 & 1.1096 & 1.1096 \\
\hline 0.8 & 1.1096 & 1.1106 & R.M. S Value \\
\hline \multicolumn{4}{|c|}{ Form Factor $=\frac{\text { R.M Value }}{0.637 \text { V V }_{\max }}$} \\
\end{tabular}

For a pure sinusoidal waveform the Form Factor will always be equal to 1.11

\section{CONCLUSION}

In this research work, MCPWM strategy based Z source five level neutral point clamped inverter have been presented. $\mathrm{Z}$ source multilevel inverter gives higher output voltage through its $\mathrm{Z}$ source network. Performance factors like \% THD, $\mathrm{V}_{\mathrm{RMS}}$ and CF, FF have been measured, presented and analyzed. It is found that it provides lower \% THD in APOD and higher V RMS in POD and less number of dominant harmonics than the other strategies. DC source can be replaced by renewable energy sources and this $\mathrm{Z}$ source five level neutral point clamped inverter can be used for distributed generation systems. 


\section{REFERENCES}

[1]. “Multilevel Inverters: A Survey of Topologies, Controls, and Applications" José Rodríguez, senior member, IEEE, Jih-Sheng Lai, senior member, IEEE, and Fang Zheng Peng, senior member, IEEE .IEEE transactions on industrial electronics, vol. 49, no. 4, August 2002.

[2]. "Multicarrier PWM with DC-Link Ripple Feed forward Compensation for Multilevel Inverters" Samir Kouro, Student Member, IEEE, Pablo Lezana, Member, IEEE, Mauricio Angulo, and José Rodríguez, Senior Member, IEEE. IEEE transactions on power electronics, vol. 23, no. 1, January 2008

[3] "Constant Boost Control of the Z-Source Inverter to Minimize Current Ripple and Voltage Stress"Miaosen Shen, Student Member, IEEE, Jin Wang, Member, IEEE, Alan Joseph, Fang Zheng Peng, Fellow, IEEE, Leon M. Tolbert, Senior Member, IEEE, and Donald J. Adams, Member, IEEE

[4]. "FPGA Control of the Neutral Point Clamped Quasi-Z-Source Inverter" S. Stepenko1,2, O. Husev1,2, D. Vinnikov1, S. Ivanets2, Ehitajate tee 5,19086 Tallinn,

[5] “Z-Source Inverter"Fang Zheng Peng, senior member IEEE. IEEE transactions on industry applications, vol. 39, no. 2, March/April 2003

[6]. "An FPGA-Based Digital Modulator for Full- or Half-Bridge Inverter Control” Diego Puyal, Luis A. Barragán, Jesús Acero, Member, IEEE, José M. Burdío, Member, IEEE, and Ignacio Millán

[7]. "Pulse-width modulated Z-source neutral-point-clamped inverter,"P. C. Loh, F. Blaabjerg, S. Y. Feng, and K. N. Soon, in Proc. IEEE APEC ${ }^{\mathrm{ce}} 06,2006$, pp. 431-437.

[8]. "Multilevel Voltage-Source-Converter Topologies for Industrial Medium-Voltage Drives" José Rodríguez, Senior Member, IEEE, Steffen Bernet, Member, IEEE, BinWu, Senior Member, IEEE,Jorge O. Pontt, Senior Member, IEEE, and Samir Kouro, Student Member, IEEE. IEEE transactions on industrial electronics, vol. 54, no. 6, December 2007

[9]. "Z-Source Inverter for Motor Drives" Fang Zheng Peng, Fellow, IEEE, Alan Joseph, JinWang, Student Member, IEEE, Miaosen Shen, Student Member, IEEE, Lihua Chen, Zhiguo Pan, Student Member, IEEE, Eduardo Ortiz-Rivera, Member, IEEE, and Yi Huang. IEEE transactions on power electronics, vol. 20, no. 4, July 2005

[10]. "Steady-State Analysis and Designing Impedance Network of Z-Source Inverters" S. Rajakaruna, L. Jayawickrama .IEEE Trans. on Industrial Electronics, vol. 58, no. 10, pp. , July 2010. 